\title{
Impact of Capital Structure on Firm's Performance: Focusing on Non-financial Listed Egyptian Firms
}

\author{
Ahmed $\operatorname{Sakr}^{1} \&$ Amina Bedeir ${ }^{2}$ \\ ${ }^{1}$ Department of Finance and Accounting, College of Management and Technology, Arab Academy for Science and \\ Technology, Alexandria, Egypt \\ ${ }^{2}$ Post Graduate Department, College of Management and Technology, Arab Academy for Science and Technology, \\ Alexandria, Egypt \\ Correspondence: Amina Bedeir, Arab Academy for Science and Technology and Maritime Transport, College of \\ Management and Technology, P. O. Box 1029, Miami, Alexandria, Egypt.
}

Received: April 27, 2019

Accepted: August 1, 2019

Online Published: August 14, 2019

doi:10.5430/ijfr.v10n6p78

URL: https://doi.org/10.5430/ijfr.v10n6p78

\begin{abstract}
The purpose of this paper is to investigate the impact of capital structure decisions on the performance of the firm. The investigation has been performed using a data of 62 listed non-financial Egyptian firms over a period of fourteen years from 2003-2016. This study used two measures for performance the dependent variable which are ROA and ROE, the most common used measures agreed upon on the majority of previous studies. Whereas, for the independent variable "the capital structure, the study uses the three measures of capital structure which are total debt to total assets (TD), total short-term debt to total assets (STD), and total long-term debt to total assets (LTD). The results showed when using ROA as a measure of performance, a significant negative impact of capital structure (TD, STD, and LTD) exists; while in case of using ROE as a measure of performance, there's a significant negative impact of capital structure only when using STD, otherwise a positive significant impact of capital structure exist.
\end{abstract}

Keywords: capital structure, firm financial performance, Egypt, emerging markets

\section{Introduction}

Capital structure decisions are one of the most crucial decisions in the field of finance. As the way a firm is financed is very important to investors, directors, stakeholders and all parties interested in the firm; because of the direct impact financing decisions have on the firm's value. Capital structure decisions refer to the proportions of debt and equity used by a firm in financing its business (Damodaran, 2001). That's why it's very important to investigate the effect of decisions about capital structure on the firm's performance.

The capital structure literature as well as it determinants was originally founded by Modigliani and Miller (1985) presenting the irrelevancy theory; proposing the assumption of the existence of perfect markets where a tax-free economy with no transaction costs, no bankruptcy costs, using either debt or equity in financing the firm's project will be the same with regards to the firm value; suggesting that the firm value depends upon profitability and risks rather that debt equity proportion. So, under the irrelevancy theory financing decisions doesn't add any value and are not of the financial managers concerns. After releasing the tax-free assumption in 1963, Modigliani and Miller argued that the debt sources of capital are very important for firms due to the privileges of tax shield gain on the interest payment. In 1973 the trade-off theory was founded by Kraus and Litzenberger, stating that the use of debt financing will remain a better source up to the extent where the benefit of debt (tax shield) higher than the cost associated with debt (bankruptcy cost). The theory proposes the existence of an optimal capital structure which maximises the firm value. The pecking order theory introduced by Myers and Majluf (1984), clarifying the preferences of firms in choosing between equity and debt. They argue that firms prefer the use of internal source of financing over external ones; while choose equity finance as their last option. Jensen and Meckling (1976) presented the agency cost theory; the theory suggests that since the agency problem derived from the information asymmetry existed in some cases, firms tend to prefer the use of debt financing over equity financing. This theory argues that the debt represents a fixed obligation that the firm must meet, through payment of debt interest and principals. Such obligations are assumed restrict any act by managers that may result in over consuming the firm's financial resources, by taking over the free cash flow of the firm if exists. 
Both empirical evidences and several studies suggest that in reality perfect markets don't exist and the assumptions of irrelevancy theory don't hold. In fact, capital structure is one of the main crucial financial decisions for any firm as it help maximising the return to the firm and impact the firm's value. Literature suggests that although an optimal capital structure does exist, there's no definite method that ensure them to achieve optimal debt level yet. While financial theory actually supports in better understanding of the effect of the chosen capital structure mix on the firm's performance. Several researchers have examined the relationship between capital structure decisions and firm's value. Desai (2007) argue that capital structure decisions have two possible effects; first, firms with higher leverage levels may have higher cost of capital than those firms with the same risk class. Secondly, firms with more leverage become riskier and consequently valued lower than less levered firms due to the probable effect of capital structure on firm's valuation. When financial managers' main aim is maximisation of the shareholders' wealth, capital structure is an important decision as it could results in the optimal financing mix that maximises the firm's per share market price.

The decision about the capital structure of a firm is determined by many factors that can be grouped mainly under main three categories which are firm specific, industry specific and country specific factors; these factors include size of the firm, profitability, corporate tax, bankruptcy costs, industry type, internal policies of the firm (Colombage and Rao, 2015). As mentioned earlier, some schools proposed the irrelevance of capital structure to the firm's performance; however, this paper aims to investigate the impact of capital structure on the performance of nonfinancial listed Egyptian firms. Examining the relationship of capital structure including: short-term debt to total assets (STD), long-term debt to total assets(LTD), and total debt to total assets (TD); and the firm performance such as return on assets (ROA), return on equity (ROE) over a period of 14 years 2003-2016. For the firm performance there are other measures mentioned in a few papers such as earnings per share (EPS), profit margin (PM), and earning multiplier (PE), however, majority of papers focused on the use of ROA and ROE as both together gives a clear picture about the firm's performance as well as the management effectiveness; also, both can benchmark the firm's ability to generate earnings from its investments. The results show that there's a significant negative relationship between leverage measured by TD, STD, and LTD and the firm's performance measured by ROE, and ROA.

This paper is organized as follow. In the next section, the literature review, theoretical and empirical evidence concerning the capital structure are reviewed, the following section presents the method of the research, and last section highlights empirical results of the empirical analysis and finishing with the conclusions that can be derived from the results.

\section{Literature Review and Hypotheses Development}

\subsection{Literature Review}

The relationship between capital structure and the firm's performance has been investigated by several empirical studies, in order to examine the existence and the direction of such relationship if existed these studies have presented some mixed results. For example; studying the Indian listed firms in 2011, Pathak revealed that leverage level has a negative significant impact on firm's performance. Although this result found to be inconsistent with other studies performed for western economies, it has proven to be conforming to those results of Asian countries. The main ground for such conflict could be due the relatively high cost of borrowing in developing countries compared to western developed countries.

With regards to capital structure choice, the theories are relatively related to the cost of capital of the firm and the main debate is concerned about the existence of an optimal capital structure and the impact of the capital structure on the cost of capital and the value of the firm. On the other hands, financial performance measured using profit margin, return on assets, and return on equity are the major effectiveness of any firm (Chakravarthy, 1986; Tian and Zeitun, 2007). Practically Tian and Zeitun (2007) argued that financial managers who managed to achieve the optimal capital structure of the firm will not only be minimising the cost of capital of the firm, but they are also maximising the firm's profitability, hence, enhancing the firm's performance and value. The main reason for this is due to the importance of the financing policy for the efficiency of the firm's performance. Theoretically, the capital structure of the firm may be containing more leverage than equity mainly for two reasons. Firstly, in 1991 Harris and Raviv argue that the interests of both managers and shareholders are adjusted by higher level of leverage. Secondly, Gleason et al., (2000) argue that managers sometimes undervalue bankruptcy cost and liquidation costs assigned to acquiring more debt. These two reasons propose leverage amount higher than appropriate in the capital structure. The existence of such case with levels of leverage higher than appropriate levels in capital structure may increase the value of firms in the short-run, while exposing the firms to higher financial distress. 
Many studies showed a positive relationship between capital structure and performance such as Roden and Lewellen (1995), Champion (1999) and Gosh et al. (2000), as well as Hadlock and James (2002) whose results indicated that firms with high profitability levels tend to use high level of leverage which is consistent to the trade-off theory of capital structure. In his study on Ghanian firms covering a period 1998-2002, Abor (2005) argued that there is a significant positive relationship between capital structure measured using total debt to total assets (TD) and short term-debt to total assets (STD), and the firm performance. Also, similar results were found by Arbiyan and Safari (2009) examining the capital structure effect on the profitability of 100 listed Iranian firm over the period 2001-2007. The results of their research show that capital structure measures by STD and TD is positively related to profitability measured by ROE while it's negatively related when using the long-term debt to total assets (LTD) as a proxy for capital structure. Moreover, when testing the impact of capital structure on the performance of Malaysian firms while focusing on the industrial and consumer sectors. Ahmad, Abdullah, and Roslan (2012) found that both STD and TD have a positive significant effect of the firm performance measured by ROA and ROE; and negative impact of LTD on the firm performance. Similar results found by Saputra, Achsani, and Anggraeni (2015), studying the effect of capital structure on firm performance over period 2009-2013 of 55 listed Indonesian firms. The result indicates that both STD and TD have a positive influence on the performance of the firm measured by ROA, while a negative impact of the LTD on the firm performance.

On the other hand, there are other studies suggesting that capital structure have a negative impact on the firm performance, Kester (1986) results show a negative relationship between capital structure and firm performance on his study performed on Japan and the US firms. Similarly, other empirical studies reported a negative relationship between leverage and performance measured using ROA. For example: Friend and Lang (1988), Titman and Wessels (1988) found same results in the studies on firms from US, Rajan and Zingales (1995) in the G-7 countries, Wald (1999) in the developed countries. In addition, the results of Wiwattanakantang (1999) after studying 270 Thai firms show a negative relationship between leverage and performance, also in 2006 Haung and Song found in their study on firms from China a negative relationship between capital structure measured using TD and performance measured by earnings before interest and taxes to total assets (EBITA). Furthermore, in 2010 Chakraborty regressed two measures of capital structure the total debt to total assets (TD) and the total debt to total equity ratio (DE) against two different measures of performance the earnings before interest, taxes and depreciation to total assets (EBITDA) ratio and the cash flows to total assets ratio. The results showed a negative relationship between capital structure and firms performance. In 2015, Foo, et al. studied the effect of capital structure measured by TD, STD, and LTD on the performance of Oil and Gas firms in Malaysia using panel data of 12 companies over the period 2003-2013; the performance was measured using ROE, ROA, and GM. The results showed a negative impact of the capital structure on the performance when measured by ROE; whereas no impact at all through a no significant relationship for capital structure with performance when measured by both ROA and GM.

Moreover, a research by Zertun and Tian (2007) examining the impact that capital structure has on corporate performance utilising a panel data sample of 167 listed Jordanian firms over the period 1989-2003. The results showed that capital structure have a negative significant effect on the performance of the firms when using both accounting and market measures. Also, Salim and Yadav (2012) investigated the impact of capital structure choice on the firm performance studying 237 Malaysian listed firms, using ROA, ROE, EPS, Tobin Q as measures for performance and TD, and STD as measures for capital structure. The result revealed that capital structure negatively impacted the firm performance. Same results presented by Ebaid (2009) who studied the impact of capital structure choice on the performance of 64 firm Egyptian firms listed in the capital market over the period 1997-2005. In 2011, the results of Pratheepkanth examining the capital structure and its impact on the financial performance over the period 2005-2009 of firms in Sri Lanka showed that; capital structure have a negative significant impact on the financial performance.

However, some other results have been consistent to the agency cost model and showing no relation and no impact of capital structure decisions on the firm performance (Jensen and Meckling, 1975). The results of Khan (2012) in his investigation he found an insignificant effect showing no impact for leverage on performance (profitability). In 2011 several studies focused on the impact of capital structure decision on financial performance, the majority of these studied have been performed on developing countries and presented similar results. Saedi and Mahmoodi investigated the relationship between capital structure choices and firm performance examining a sample of 320 listed nonfinancial Iranian firms over the period 2002-2009. As for the dependent variable the study use four performance measures (ROA, ROE, EPS, and Tobin's Q), and as for the independent variable a use of three capital structure measures (TD, STD, and LTD). The results reveal that when performance is measured using EPS and Tobin's Q it's a positively significantly related to capital structure; whereas there's a significant negative association 
between capital structure and ROA and no relationship between ROE and capital structure. Similarly, in a study performed on 44 non-financial firms listed in the Nairobi Stock Exchange; the study investigated the relationship between capital structure measured by TD and TSD, and the firm performance measured by ROA and ROE. Mwangi, Makau, and Kosimbei (2014) found no relation for capital structure on firm performance; the results indicate that there was an insignificant negative relationship between financial leverage and performance of non-financial companies listed in the NSE as measured by return on assets. These findings are consistent with the capital structure irrelevance theory that was first postulated by Modigliani \& Miller (1963). These traditional capital structure theories argue that the amount of debt in the capital structure does not affect performance and the value of the firm. However, Abdul (2012) concluded that financial leverage has a significant negative relationship with the firm performance as measured by return on assets (ROA). The findings of this present thesis contradicted the empirical results obtained by Saeedi \& Mahmoodi (2011), who concluded that financial leverage is positively related to performance as measured by return on assets.

Furthermore, studies about the effect of capital structure on firm's performance has shown that Nigerian firms rely mainly on short-term debt as it's up to 60 percent of total debt (Salawu, 2007). Similar results have been reported by Myers (2001) that; the studied US firms use small proportion as for capital formation and the equity issues are lesser, and the large amount of external finance from short-term debt. Although the assumptions of Nigerian firms proposed by Salawu, 2007 matches those of US firms proposed by Myers (2001); evidence for publicly traded Nigerian firms argue that the proposition of external finance covers only a small proportion of capital structure is not true (Ahmad, Abdullah, and Roslan, 2012).

\subsection{Hypotheses Development}

The majority of literature regarding the impact of capital structure on the firm's performance relied heavily on the pecking order theory and the agency cost theory (Riahi-Belkaoui, 1999), proposing either a significant negative relationship between capital structure and firm's performance for the pecking order theory or a significant positive relationship between capital structure and firm's performance with regards to agency cost theory. However, there is slight evidence on the trade-off theory, proposing a significant positive relationship between capital structure and firm's performance.

H: Capital structure has a significant impact on firm's performance

\section{Description of Data and Methodology}

\subsection{Data}

The study uses annual data of non-financial listed companies in the Egyptian Stock Exchange over a period of 14 years from 2003 till 2016. We exclude the financial companies and the banking sector due to the uniqueness of their capital structure and the strict legal requirements for their financing choices (Gaud et al., 2005) in line with most previous literature. The Egyptian Stock Exchange has 251 listed companies in 2016 representing 17 different sectors. The majority of companies are in the food and beverage and the industrial goods and services sectors. Our final sample consists of 62 Egyptian companies was obtained for a period of 14 years resulting in 868 observations and covering 12 industries, the Table 1 summarises the classification of firms across the various industries. The main source for the data used is the Egyptian Stock Exchange (EGX) and the Egyptian Financial Regulatory Authority (EFRA) as they contain the authorized information for listed companies as well as the different Industries.

Table 1. Classification of the used sample of listed companies

\begin{tabular}{ll}
\hline Sector & No. of Firms in the Sector \\
\hline Basic Resources & 2 \\
\hline Chemicals & 3 \\
\hline Construction and Materials & 4 \\
\hline Oil and Gas & 2 \\
\hline Food and Beverage & 16 \\
\hline Healthcare & 8 \\
\hline Media & 1 \\
\hline
\end{tabular}




\begin{tabular}{ll}
\hline Industrial Goods and Services & 12 \\
\hline Personal and Household products & 8 \\
\hline Technology & 1 \\
\hline Travel and Leisure & 1 \\
\hline Real Estate and Housing & 4 \\
\hline Total & 62 \\
\hline
\end{tabular}

\subsection{Empirical Models}

The main model to investigate the impact of capital structure on the performance of the firm is as follow:

$$
P E R F_{i, t}=\beta_{0 i, t}+\beta_{1} L E V_{i, t}+\varepsilon_{i, t}
$$

$P E R F_{i, t}$ : is a measure of performance taken by the most common proxies ROA and ROE (Ang et al., 2000; Abdel Shahid, 2003; Abor, 2005; Tian and Zeitun, 2007; Saedi and Mahmoodi, 2009; and Ebaid, 2009) for firm (i) at time $(\mathrm{t}) ; \varepsilon_{i, t}$ is the random error. We use three measures for capital structure main proxies for leverage: total debt to total assets (TD), short-term debt to total assets (STD) and long-term debt to total assets (LTD).

\section{Results}

This section first presents the descriptive statistics, correlation matrix, and VIF results; then discusses the main results; and finally compares these results with those found in the Middle East and emerging countries.

\subsection{Descriptive Statistics}

The dependent variable is the performance of the firm measured using two main proxies ROA and ROE while the independent variable is the capital structure of the firm measured as the proportion of leverage using three proxies for leverage total debt to total assets (TD), total short-term debt to total assets (STD), and total long-term debt to total assets (LTD).

Table 2 presents a summary of the descriptive statistics; from these results, we can conclude the following:

- $\quad$ For the dependent variable "firm performance", the mean is 0.07 and 0.13 for ROA and ROE respectively. This may indicate that the Egyptian listed firms have a relatively very weak performance during the tested period over years 2003-2016.

- For the independent variable "capital structure", the mean is $46 \%, 38 \%$, and $8 \%$ for TD, STD, and LTD respectively.

Table 2. Descriptive statistics

\begin{tabular}{llllllll}
\hline Variable & Mean & Median & Std. Dev. & Min. & Max & Skewness & Kurtosis \\
\hline Return on Assets (ROA) & 0.071 & 0.067 & 0.12 & -0.17 & 0.25 & -1.20 & 20.96 \\
\hline Return on Equity (ROE) & 0.13 & 0.12 & 0.34 & -0.35 & 0.81 & -2.50 & 25.05 \\
\hline Total Debt to Total Assets & 0.46 & 0.44 & 0.28 & 0.002 & 1.05 & 0.17 & -0.74 \\
\hline Long-Term Debt to Total Assets & 0.08 & 0.02 & 0.17 & .001 & 0.98 & 5.57 & 17.02 \\
\hline Short-Term Debt to Total Assets & 0.38 & 0.36 & 0.22 & 0 & 0.99 & 0.92 & 3.55 \\
\hline
\end{tabular}

The results of the descriptive statistic show that the capital structure percentage shown in the sample is relatively low around $46 \%$ for total debt to total assets, $38 \%$ for the short-term debt to total assets, and $8 \%$ for long-term debt to total assets.

With regards to performance, Ebaid (2009) shows similar results on his research performed on listed non-financial Egyptian firms during a period from 1997-2005. The results of his research also indicated a relatively poor performance for the listed Egyptian firms over the tested period. As performance reported a mean of 0.0724, 0.214, and 0.245 for the performance measures ROA, ROE, and gross margin (GM) respectively. 
Tables 3 the correlation matrix using ROA as constant at the first model and then ROE as the constant for the second model; whereas table 4 presents the VIF results using TD, STD and LTD as independent variables. The pairwise correlation seems to be low between the explanatory variables so the possible problem of multicollinearity is eliminated. None of these correlations were significant; since the correlations are lower than 0.70 .

Table 3. Pearson correlation coefficients

\begin{tabular}{lllll}
\hline Variables & ROA & TD & STD & LTD \\
\hline ROA & 1 & -0.333 & -0.185 & -0.286 \\
\hline TD & & 1 & 0.605 & 0.492 \\
\hline STD & & & 1 & -0.120 \\
\hline LTD & & & & 1 \\
\hline Variables & ROE & TD & STD & LTD \\
\hline ROE & 1 & 0.008 & -0.103 & 0.164 \\
\hline TD & & 1 & 0.605 & 0.492 \\
\hline STD & & & 1 & -0.120 \\
\hline LTD & & & & 1 \\
\hline
\end{tabular}

Performance found to have a non-significance correlation with all capital structure measures (TD, STD, and LTD) when using ROA, and ROE as the measure of performance. The negative association between performance measured by ROA and capital structure measures indicate that as the debt proportions increase in the firm's capital structure, the performance of the firm declines. On the other hand, ROE associated positively with capital structure under both measures TD and LTD, while negatively associated when STD measure is used.

Also, the VIF results presented in table 4 indicate that the regression equation is free of multicollinearity under all the three ranges of time as VIF is less than 5.

Table 4. Capital structure VIF results

\begin{tabular}{ll}
\hline Variable & VIF Test Results \\
\hline TD & 1.00 \\
\hline STD & 1.00 \\
\hline LTD & 1.00 \\
\hline Mean VIF & 1.00 \\
\hline
\end{tabular}

\subsection{Main Results}

This section presents the main regression results. Based on OLS regression results, capital structure measures are found to be statistically significant using either ROA or ROE as dependent variable. Table 5 presents the main regression results.

Table 5. OLS regression results

\begin{tabular}{llll}
\hline Variables & & Model 1 ROA & Model 2 ROE \\
\hline \multirow{3}{*}{ Constant } & Expected Sign & & \\
\cline { 2 - 4 } & Coefficient & 0.151 & 0.121 \\
\cline { 2 - 4 } & $\mathrm{T}$ & 17.724 & 4.855 \\
\cline { 2 - 4 } & Sig. & 0.00 & 0.00 \\
\hline
\end{tabular}




\begin{tabular}{llll}
\hline \multirow{4}{*}{ TD } & Expected Sign & - & + \\
\cline { 2 - 4 } & Coefficient & -0.178 & 0.011 \\
\cline { 2 - 4 } & $\mathrm{T}$ & -10.53 & 0.228 \\
\cline { 2 - 4 } STD & Sig. & 0.00 & 0.019 \\
\cline { 2 - 4 } & Expected Sign & - & + \\
\cline { 2 - 4 } & Coefficient & -0.113 & -0.174 \\
\cline { 2 - 4 } & $\mathrm{T}$ & -5.631 & -3.104 \\
\cline { 2 - 4 } LTD & Sig. & 0.00 & 0.002 \\
\cline { 2 - 4 } & Expected Sign & - & + \\
\cline { 2 - 4 } & Coefficient & -0.256 & 0.407 \\
\cline { 2 - 4 } & Sig. & -8.911 & 4.984 \\
\hline Number of Observations & 0.00 & 0.00 \\
\hline Adjusted R Square & 868 & 868 \\
\hline Chi-Square & & 0.333 & 0.347 \\
\hline Chi-Square test for independence P-value & 0.00 & 14.56 \\
\hline Durbin Watson & & 1.938 & 1.958 \\
\hline
\end{tabular}

The results of the regression show that, at confidence level of $90 \%$ the P-Value is less than 0.1 for all variables, hence there's a significant relationship between capital structure and firm performance. Under the use of ROA as a measure of the performance, the coefficient of capital structure is negative when using TD, STD, and LTD. Thus, there's a negative significant relationship between capital structure and performance of the firm; which suggests that the increase in the leverage in the firm's capital structure will be associated with a decrease in ROA. However, under the use of ROE as a measure of performance, the coefficient of capital structure is positive when using TD, and LTD, while negative when using STD.

Based on the results of the regression analysis, and conforming to the literature, there's a significant relationship ship between capital structure and the performance of the firm. Meaning that, capital structure does have an impact and influence on the performance of the firm. Conforming to the second hypothesis, capital structure (TD, STD, and LTD) have a proven to negatively influence the performance of the firm when using ROA as a measure of performance. While when using ROE as a measure of performance a hybrid results conforming to both the first and the second hypotheses; capital structure showed a positive relationship with the performance of the firm under the measures TD and LTD, and negative relationship with the performance of the firm under the measure STD.

The results of this research is consistent with previous studies performed, especially those applied mainly on emerging countries such as Jordan, Iran, Malaysia, Indonesia, Sri Lanka and Ghana; also some studies applied on the US and Japan showed exactly the same results. The studies on the above countries have shown similar results of a significant negative relationship between capital structure measured by TD, STD, and LTD and the performance of the firm measured by ROA; whereas a mixed relationship between capital structure and performance of the firm measured by ROE, a significant positive relationship under the measures TD and LTD, and negative relationship under the measure STD (Rajan and Zingales, 1995; Zertun and Tian, 2007; Arbiyan and Safari, 2009; Pratheepkanth, 2011; Salim and Yadav, 2012; and Saputra, Achsani, and Anggraeni, 2015).

Moreover, the results of the study presented by Ebaid (2009) show a negative relationship between capital structure measured by TD, STD, and LTD, and the performance of the firm measured by ROA. However, the results show a non-significant relationship between ROE and capital structure under TD, STD, and LTD. Also, his results suggested that that capital structure choice, in general terms, has a weak-to-no significant impact on Egyptian listed firms' performance. Such results contradict with findings of the previous studies and literature that documented a significant impact of capital structure of capital structure on firm performance either positively (Gosh et al., 2000; Abor, 2005; Kyereboah-Coleman, 2007) or negatively (Balakrishnan and Fox, 1993; Majumdar and Chibber, 1999; 
Gleason et al., 2000; Zeitun and Tian, 2007; Abor, 2007) in both developed or developing countries. The reason of such contradicting results could be due to the majority of listed firms Egypt within the used sample by Ebaid (2009) belonged to public sector before the mid-1990s and gone to private (fully or partially) through the privatization policy adopted by Egyptian government during the tested period. Therefore, these firms may have been still suffering from some problems of those of the public sectors in Egypt as the lack of managerial skills, excessive employees' numbers, and/or the increase of obsolete fixed assets and inventories amounts in the total assets. Such problems may cause a negative impact on the firm's performance.

\section{Conclusion}

This study investigates the effect of the decision of capital structure on the firm's performance of listed Egyptian non-financial firms. The study uses three measures for capital structure which are total debt to total assets (TD), total short-term debt to total assets (STD), and total long-term debt to total assets (LTD); and for the firm performance two measures are used the return on assets (ROA) defined as the total net income to total assets, and the return on equity (ROE) defined as the total net income to total equity. Several studies have investigated the impact of the capital structure on the firm performance while a very few empirically investigated such impact on developing and transitional economies such as Egypt.

Based on the used sample of listed Egyptian nonfinancial firms, and using the above mentioned accounting based measures for capital structure and firm performance, the results indicated that capital structure (TD, STD, and LTD) have a negative impact on the firm performance measured by ROA which is consistent with results of Ebaid (2009) who also documented the same results in his empirical study on Egypt. On the other hands, capital structure (TD, and LTD) has a positive impact in the firm performance measured by ROE which is consistent with Champion (1999), Gosh et al (2000), Hardlock and James (2002), Frank and Goyal (2003) and Berger and Bonaccora di Patti (2006), whereas a negative impact of capital structure (only STD) on the firm performance measured by ROE which is consistent with results of Salim and Yadav (2012) in their study on Malaysia.

These results reveal that the choice and the decision about capital structure have a significant impact on and influence the performance of firms in Egypt. However, such issues related to capital structure decisions is still controversial and need further investigation specially in transition or emerging markets such as Egypt. Further researches could take into consideration the impact of ownership structure either solely or jointly with capital structure, also taking into consideration some control factors that affect both capital structure and the firm performance such as the size of the firm, the growth opportunities. Moreover, other measures of the firm performance could be tested such as earnings before interest and taxes to total assets, gross margin, and/or Tobin Q.

\section{References}

Abdul, G. K. (2012). The Relationship of Capital Structure Decisions with Firm Performance: A Study of the Engineering Sector of Pakistan. International Journal of Accounting and Financial Reporting, 2(1), 2162-3082. https://doi.org/10.5296/ijafr.v2i1.1825

Abor, J. (2005). The effect of capital structure on profitability: an empirical analysis of listed firms in Ghana. Journal of Risk Finance, 6, 438-447. https://doi.org/10.1108/15265940510633505

Abor, J. (2007). Debt policy and performance of SMEs: evidence from Ghanaian and South Africa firms. Journal of Risk Finance, 8, 364-79. https://doi.org/10.1108/15265940710777315

Ahmad, Z., Abdullah, N. M. H., \& Roslan, S. (2012, July). Capital Structure Effect on Firms Performance: Focusing on Consumers and Industrials Sectors on Malaysian Firms. International Review of Business Research Papers, $8(5), 137-155$.

Arbabiyan, A.-A., \& Safari, M. (2009). The effects of capital structure and profitability in the listed firms in Tehran Stock Exchange. Journal of Management Perspective, 33, 159-175.

Berger, A., \& Bonaccorsi di Patti, E. (2006). Capital structure and firm performance: a new approach to testing agency theory and an application to the banking industry. Journal of Banking and Finance, 30(4), 1065-1102. https://doi.org/10.1016/j.jbankfin.2005.05.015

Boodhoo, R. (2009). Capital Structure and performance of Mauritius Listed Firms: Theoretical and Empirical Evidences. Online Web.

Booth, L., Aivazian, V., Hunt, A., \& Maksimovic, D. (2001). Capital structure in developing countries. Journal of Finance, 56, 87-130. https://doi.org/10.1111/0022-1082.00320 
Bradley, M., Jarell, G. A., \& Kim, E. H. (1984). On the existence of an Optimal Capital Structure: The Theory and Evidence. Journal of Finance, 39, 857-880. https://doi.org/10.1111/j.1540-6261.1984.tb03680.x

Brav, A., Graham, J., Harvey, C., \& Michaely, R. (2005). Payout policy in the 21st century. Journal of Financial Economics, 77, 483-527. https://doi.org/10.1016/j.jfineco.2004.07.004

Chakraborty, I. (2010). Capital structure in an emerging stock market: The case of India. Research in International Business and Finance, 24, 295-314. https://doi.org/10.1016/j.ribaf.2010.02.001

Champion, D. (1999). Finance: the joy of leverage. Harvard Business Review, 77, 19-22.

Chen, J. J. (2004). Determinants of Capital Structure of Chinese Listed Companies. Journal of Business Research, 57, 1341-1351. https://doi.org/10.1016/S0148-2963(03)00070-5

Dada, A. O., \& Ghazali, Z. (2016). The Impact of Capital Structure on Firm Performance: Empirical Evidence from Nigeria. Journal of Economics and Finance, 7(4), 23-30. https://doi.org/10.9790/5933-0704032330

Deesomsak, R., Paudyal, K., \& Pescetto, G. (2004). The determinants of capital structure: Evidence from the Asia Pacific region. Journal of Multinational Financial Management, 14, 387-405. https://doi.org/10.1016/j.mulfin.2004.03.001

Ebaid, I. E. (2009). The impact of capital structure choice on firm performance: empirical evidence from Egypt. The Journal of Risk Finance, 10(5), 477-487. https://doi.org/10.1108/15265940911001385

Eriotis, N., Vasiliou, D., \& Neokosmidi, V. Z. (2007). How firm characteristic affect capital structure: an empirical study. Journal of Managerial Finance, 33(5), 321-331. https://doi.org/10.1108/03074350710739605

Frank, M., \& Goyal, V. (2003). Testing the pecking order theory of capital structure. Journal of Financial Economics, 67, 217-248. https://doi.org/10.1016/S0304-405X(02)00252-0

Friend, I., \& Lang, L. H. P. (1988). An empirical test of the impact of managerial self-interest on corporate capital structure. Journal of Finance, 43(2), 271-281. https://doi.org/10.1111/j.1540-6261.1988.tb03938.x

Ghosh, C., Nag, R., \& Sirmans, C. (2000). The pricing of seasoned equity offerings: evidence from REITs. Real Estate Economics, 28, 363-84. https://doi.org/10.1111/1540-6229.00805

Hadlock, C., \& James, C. (2002). Do banks provide financial slack?. Journal of Finance, 57, 1383-420. https://doi.org/10.1111/1540-6261.00464

Harris, M., \& Raviv, R. (1991). The Theory of Capital Structure. Journal of Finance, 46(1), 297-355. https://doi.org/10.1111/j.1540-6261.1991.tb03753.x

Heinkal, R. (1982). A theory of capital structure relevance under imperfect information. Journal of Finance, 37, 1141-1150. https://doi.org/10.1111/j.1540-6261.1982.tb03608.x

Hovakimian, A., Hovakimian, G., \& Tehranian, H. (2004). Determinants of target capital structure: The case of dual debt and equity issues. Journal of Financial Economics, 71(3), 517-540. https://doi.org/10.1016/S0304-405X(03)00181-8

Huang, S., \& Song, F. M. (2006). The Determinants of Capital Structure: Evidence from China. China Economic Review, 17, 14-35. https://doi.org/10.1016/j.chieco.2005.02.007

Jensen, M., \& Meckling, W. (1976). Theory of the firm: managerial behavior, agency costs and capital structure. Journal of Financial Economics, 3, 11-25. https://doi.org/10.1016/0304-405X(76)90026-X

Jermias, J. (2008). The relative influence of competitive intensity and business strategy on the relationship between financial leverage and performance. The British Accounting Review, 40, 71-86. https://doi.org/10.1016/j.bar.2007.11.001

Kester, W. (1986). Capital and ownership structure: a comparison of United States and Japanese manufacturing corporations. Financial Management, 15, 5-16. https://doi.org/10.2307/3665273

Khan, I. (2012). Capital Structure, Equity Ownership and Firm Performance: Evidence from India. Social Science Research Network, Online Web. https://doi.org/10.2139/ssrn.2016420

Kouki, M. (2012). Capital Structure Determinants: New Evidence from French Panel Data. International Journal of Business and Management, 7(1), 214-229. https://doi.org/10.5539/ijbm.v7n1p214

Kumar, S., Colombage, S., \& Rao, P. (2017). Research on capital structure determinants: a review and future directions. International Journal of Managerial Finance, 13(2), 106-132. 
Li, J. M., Shi, C. Q.., \& Wang, Z. H. (2010). An Empirical Analysis of Debt Financing on Firm Investment Behavior: Evidence From China. Journal of Information Science and Management Engineering, 2, 356-359.

Majumbar, S., \& Chhibber, P. (1999). Capital structure and performance: evidence from a transition economy on an aspect of corporate governance. Public Choice, 98, 287-305. https://doi.org/10.1023/A:1018355127454

Miller, M. (1977). Debt and Taxes. Journal of Finance, 32, 262-275. https://doi.org/10.1111/j.1540-6261.1977.tb03267.x

Modigliani, F., \& Miller, M. (1963). Corporate income taxes and cost of capital: a correction. American Economic Review, 53, 443-453.

Mwangi, L. M., Makau, M. S., \& Kosimbei, G. (2014). Relationship between Capital Structure and Performance of Non-Financial Companies Listed In the Nairobi Securities Exchange, Kenya. Global Journal of Contemporary Research in Accounting, Auditing and Business Ethics (GJCRA), 1(2).

Myers, S. (1977), Determinants of corporate borrowings. Journal of Financial Economics, 5, 147-175. https://doi.org/10.1016/0304-405X(77)90015-0

Pirzada, K., Bin Mustapha, M. Z., \& Wickramasinghe, D. (2015). Firm Performance, Institutional Ownership and Capital Structure: A Case of Malaysia. Global Conference on Business and Social Science. https://doi.org/10.1016/j.sbspro.2015.11.025

Pratheepkanth, P. (2011). Capital Structure and Financial Performance: Evidence from Selected Business Companies in Colombo Stock Exchange Sri Lanka. Journal of Arts, Science \& Commerce, II(2), 1-13.

Rajan, R. G., \& Zingales, L. (1995). What do we know about capital structure? Some evidence from international data. Journal of Finance, 50(5), 1421-1460. https://doi.org/10.1111/j.1540-6261.1995.tb05184.x

Rajesh, P. (2011). Capital Structure and Performance: Evidence from Indian Manufacturing Firms. Social Science Research Network. Online Web.

Ramaswamy, K. (2001). Organizational ownership, competitive intensity, and firm performance: an empirical study of Indian manufacturing sectors. Strategic Management Journal, 22, 989-998. https://doi.org/10.1002/smj.204

Razak, N. H. A., Ahmad, R., \& Aliahmed, H. J. (2008). Government ownership and performance: An analysis of listed companies in Malaysia. Corporate Ownership and Control, 6(2), 434-442.

Rezaei, J., \& Ortt, R. (2018). Entrepreneurial orientation and firm performance: the mediating role of functional performances. Management Research Review, 41(7), 878-900. https://doi.org/10.1108/MRR-03-2017-0092

Roden, D., \& Lewellen, W. (1995). Corporate capital structure decisions: evidence from leveraged buyouts. Financial Management, 24, 76-87. https://doi.org/10.2307/3665536

Saeedi, A., \& Mahmoodi, I. (2011). Capital Structure and Firm Performance: Evidence from Iranian Companies. International Research Journal of Finance and Economics, 70, 21-28.

Salim, M., \& Yadav, R. (2012, December). Capital Structure and Firm Performance: Evidence from Malaysian Listed Companies. International Congress on Interdisciplinary Business and Social Science, 65(3), 156-166.

San, O. T., \& Heng, T. B. (2011). Capital Structure and Corporate Performance of Malaysian Construction Sector. International Journal of Humanities and Social Science, 1(2), 28-36.

Saputra, T., Achsani, N. A., \& Anggraeni, L. (2015, August). The Effect of Capital Structure on Firm Performance: Empirical Evidence from the Indonesian Financial Industry. International Journal of Business and Management Invention, 4(8), 57-66.

Taub, A. (1975). Determinants of firm s capital structure. Review of Economics and Statistics, 57, 410-416. https://doi.org/10.2307/1935900

Titman, S., \& Wessels, R. (1988). The determinants of capital structure choice. Journal of Finance, 43(1), 1-19.

Wald, J. (1999). How firm characteristics affect capital structure: an international comparison. Journal of Financial Research, 22, 161-87. https://doi.org/10.1111/j.1475-6803.1999.tb00721.x

Warner, J. (1977). Bankruptcy costs: some evidence. Journal of Finance, 32, 337-347. https://doi.org/10.2307/2326766

Zeitun, R., \& Tian, G. (2007). Capital structure and corporate performance: evidence from Jordan. Australasian Accounting Business and Finance Journal, 1, 40-53. https://doi.org/10.14453/aabfj.v1i4.3 